\title{
ANALYSIS AND ASSESSMENT OF WATER DISTRIBUTION SUBSYSTEM FAILURE
}

\section{ANALIZA I OCENA AWARYJNOŚCI PODSYSTEMU DYSTRYBUCJI WODY}

\author{
Katarzyna Pietrucha-Urbanik, Katarzyna Pociask \\ Rzeszow University of Technology \\ e-mail:kpiet@prz.edu.pl
}

\begin{abstract}
The aim of the study is to analyse and assess the water supply network failure frequency in last ten years, with particular emphasis on the last year of the analysis. The analysis is based on actual data obtained from the water company. The study contains the analysis of the network failure with division into used material, the type of network and place of failure occurrence. Also the failure rate was calculated. Continuous changes in the age and material structure of the water network cause the need for conducting failure frequency research because data on failure rate are the key indicators for operational policy of water supply systems.
\end{abstract}

Keywords: water network, failure, failure rate

Streszczenie: Celem pracy jest analiza $i$ ocena awaryjności sieci wodociagowej $w$ ostatnim dziesięcioleciu, ze szczególnym uwzględnieniem ostatniego roku analizy. Podstawa analizy sa rzeczywiste dane uzyskane $z$ przedsiębiorstwa wodociagowego. Opracowanie zawiera analize awaryjności sieci $z$ podziałem na zastosowany materiat, rodzaj sieci $i$ miejsce wystepowania. Ciagłe zmiany struktury wiekowej oraz materiałowej sieci wodociagowych, powoduja konieczność prowadzenia badań awaryjności, ponieważ dane te sa jednym z głównych wskaźników dla polityki eksploatacyjnej sieci wodociagowych.

Stowa kluczowe: wodociagi, awaryjność, intensywność uszkodzeń 


\section{ANALYSIS AND ASSESSMENT OF WATER DISTRIBUTION SUBSYSTEM FAILURE}

\section{Introduction}

Failures occurring in water distribution networks concern, without exception, each operating water network, although the failure frequency of water supply system is various and depends, among others, on the type of used material or the time of water supply network operation $[2,8]$. The consequences of the failure occurrence can be the pressure drop in the network and water losses $[1,9,10]$. Water companies tend to minimize water losses, as well as the number of failures, according. For this purpose, the analysis of the water supply system functioning is made, which aim is to illustrate the condition of water supply network. In many scientific centres the research concerning proper functioning of the water supply network are conducted [3-5, 12]. These research concern water supply network failures among others in terms of their causes and number. One of the indicators describing the state of the given segment of water supply network is the failure rate, which may be the basis for planning the renewal strategy of the water supply system, aimed to reduce the number of network failures, as to supply recipients with water of proper quality and quantity [13]. For this reason, in the paper the analysis and assessment of the water supply network failure frequency in the last ten years, for a chosen city in the Podkarpackie province, with the population of 39375 inhabitants and an area of $38.08 \mathrm{~km}^{2}$, was presented.

\section{Characteristics of the analysed water supply network}

The analysed water supply network operates in a radial ring scheme. In 2015 the length of this network was $342,71 \mathrm{~km}$. Almost $60 \%$ of the entire length of the network are sections being no more than ten years old, the sections used for 25 years make $30 \%$, the remaining part can be even up to 50 years old. In $2015,39 \%$ of sections were made of PE, $31 \%$ of grey cast iron, $16 \%$ of PVC and $14 \%$ of steel. It can be noticed a gradual reduction in the water supply system made of cast iron and steel, a very large increase in the pipes made of PE (Figure 1).

The biggest change in the structure of the material occurred in 2013, sections of cast iron and steel were replaced by pipes made of PE.

Over the 14 years the analysed water supply network extended from $174,2 \mathrm{~km}$ to $342,71 \mathrm{~km}$, which gives almost $97 \%$ increase in the network length. Every year, the network length increased of about few kilometres, a very large increase $(43,9 \mathrm{~km})$ occurred in 2013, which was the result of expansion of the water treatment plant in Trepcza. In 2015 the network length increased of about $66 \mathrm{~km} \mathrm{(24 \% ).} \mathrm{The} \mathrm{length}$ of the main network for all these years remained unchanged, as well as water supply connections in the period of 2002-2012. 


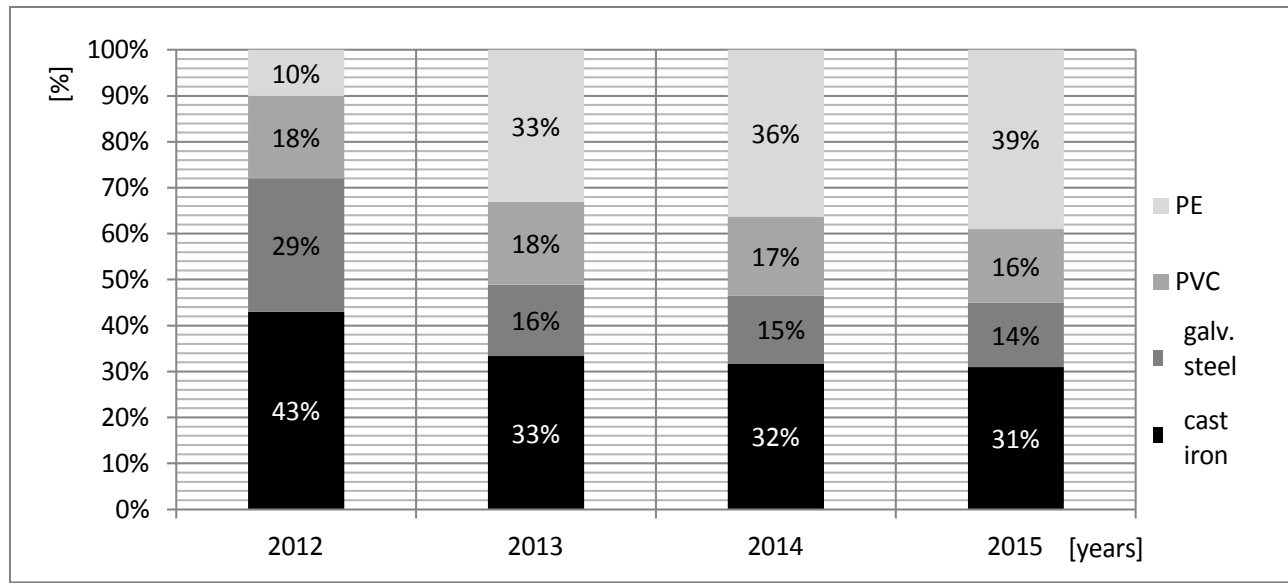

Fig. 1. The percentage material structure of the water supply network in the years 2012-2015.

Over the analysed years the water production remained at the same level. Since 2011, the volume of production constantly decreased, taking the lowest value in 2014. (the decrease in the volume of production by 13\%). The amount of water flowing into the network is lower than the consumed water of about $6-7 \%$. The percentage of water consumption before pumping into the network in the years 2002-2012 ranges from 4,5-6\%, and in 2013-2015 this value increased almost in double.

Most water was sold to the households, $76 \%, 17 \%$ was sold to other users, such as offices, hospitals, schools and the remaining $6 \%$ is water sold to the industry. The water sale within 14 years has decreased by more than $22 \%$. Considering the fact that in those years the length of water supply network significantly increased, it may be supposed that the reason for such a decline in water sale can be, among others, closing industrial plants and building own water intakes, in order to reduce costs. Such conclusions can be drawn by comparing the sale of water for the industry in 2002 to the sale in 2015, where the decline was $72 \%$. Also for other consumers this number decreased by $26 \%$, the lowest drop, $5 \%$, in sale for the households.

\section{Analysis of the water supply network failure frequency}

\section{The failure rate of the network depending on the pipe function}

The failure rate of the network was determined as the number of failures falling to the length of pipe [7]. The boundary values of the failure rate depending on the pipe type are as follows: for mains $\lambda \leq 0,3$ failures $\mathrm{km}^{-1} \cdot \mathrm{a}^{-1}$, for distribution pipes $\lambda$ $\leq 0,5$ failures $\cdot \mathrm{km}^{-1} \cdot \mathrm{a}^{-1}$ and for water connections $\lambda \leq 1,0$ failures $\cdot \mathrm{km}^{-1} \cdot \mathrm{a}^{-1}[10]$. 
Analysis and assessment of water distribution subsystem failure Analiza i ocena awaryjności podsystemu dystrybucji wody

Analysing the data shown in Figure 2, it can be seen that the highest failure rate is characteristic for the mains.

The average failure rate in these pipes in the period from 2006 to 2015 amounted to 1,78 failures $\cdot \mathrm{km}^{-1} \cdot \mathrm{a}^{-1}$.

The number of failures in the mains is not large because it varies within the range of 14-26, however, in relation to the length of network, $11,2 \mathrm{~km}$, it gives the highest failure rate. In turn, the average failure rate of water supply connections is 0,84 failures $\cdot \mathrm{km}^{-1} \cdot \mathrm{a}^{-1}$. In the distribution pipes the average failure rate was only 0,39 failures $\cdot \mathrm{km}^{-1} \cdot \mathrm{a}^{-1}$.

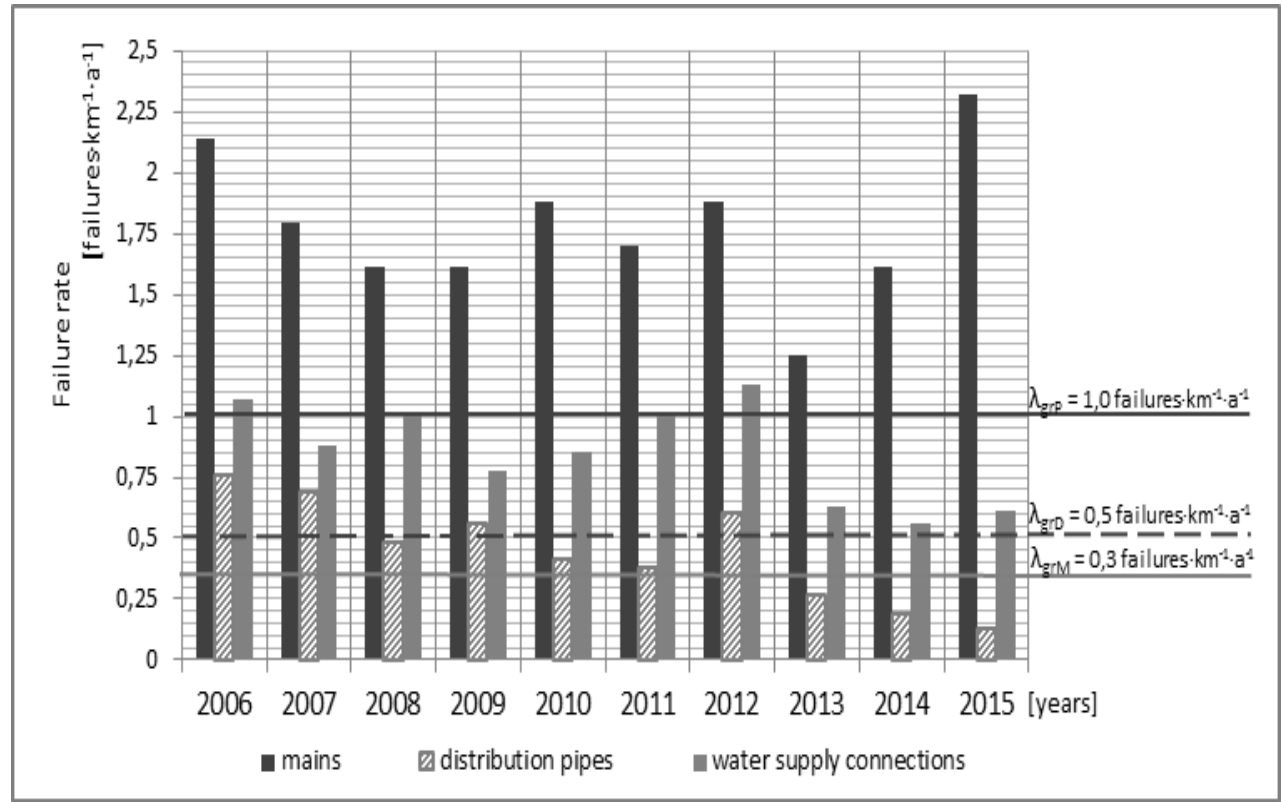

Fig. 2. The failure rate of individual pipes of the water supply network in the years 2006-2015

It can be concluded that the main network is almost 5 times more vulnerable to failure occurrence than the distributional pipes. According to the criteria adopted in Poland, the mains exceed the recommended value almost six times [10]. Since 2013 the failure rate of the distributional pipes definitely decreased, due to replacement of a large part of the network and the use of plastic materials, as well as a significant increase in the network length (37\%) during the studied period of three years. In the last years of the analysis the failure rate of the water supply connections was lower, $\lambda \leq 1,0$ failures $\cdot \mathrm{km}^{-1} \cdot \mathrm{a}^{-1}$, only in the years 2006,2008 and 2012 the failure rate exceeded the criteria value. 


\section{The failure rate of the network depending on pipe material}

In the Figure 3 the failure rate for different pipe material in the years 2002-2015 was shown.

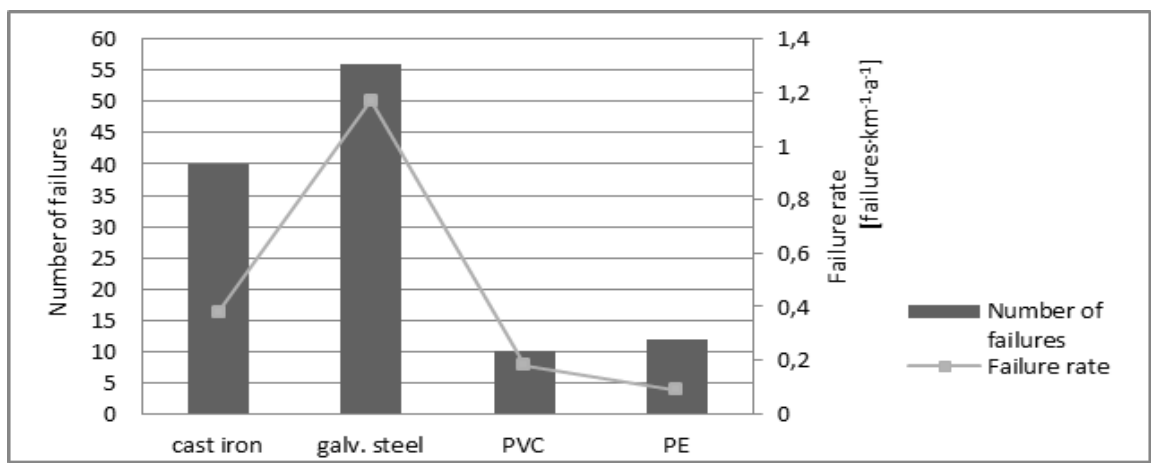

Fig. 3. The failure rate depending on the used pipe material in 2015

The most prone to failures are pipes made of galvanized steel. The failure rate for these pipes in all the years except 2012 is the highest. Over the years, the least failures occurred in the network made of PVC and since 2013 in the network made of PE.

\section{Seasonality of failure rate frequency}

In the Figure 4 the values of failure rate in division into seasons in the years 20062015 and in the Figure 5 the failure rate depending on the pipe function and failure seasonality, were shown.

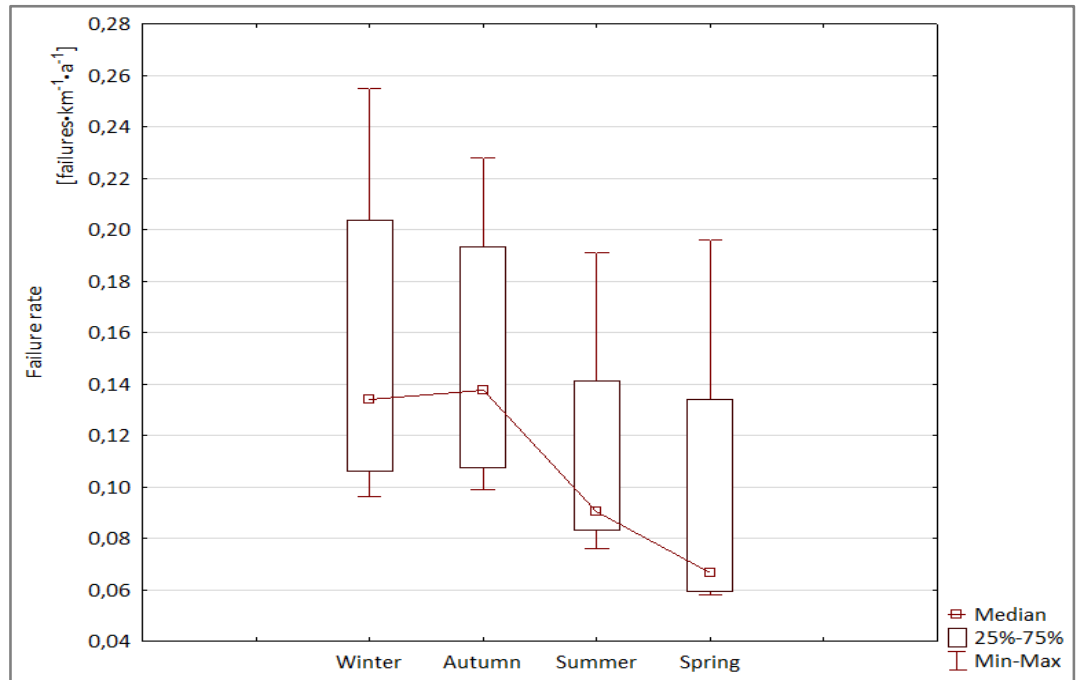

Fig. 4. The failure rate of water pipe network in division into seasons in the years 2006-2015 
Analysis and assessment of water distribution subsystem failure Analiza i ocena awaryjności podsystemu dystrybucji wody

The average value of the failure rate is the highest in the winter season and equals 0,1547 failures $\cdot \mathrm{km}^{-1} \cdot \mathrm{year}^{-1}$. The lowest value of this indicator is in the spring, then its average value is 0,096 failures $\mathrm{km}^{-1} \cdot \mathrm{year}^{-1}$. In 2015 the highest value of the failure rate occurs in the mains, in June amounted to 0.446 failures $\mathrm{km}^{-1} \cdot \mathrm{year}^{-1}$, and in April, November and December 0,268 failures $\cdot \mathrm{km}^{-1} \cdot \mathrm{year}^{-1}$. In June 2015 the distributional pipes were characterized by a value of 0,022 failures $\mathrm{km}^{-1} \cdot \mathrm{year}^{-1}$, while the failure rate of the water supply connections at that time reached a value of 0,07 failures $\mathrm{km}^{-1} \cdot \mathrm{year}^{-1}$, with a maximum value occurring in December $\left(0,12\right.$ failures $\cdot \mathrm{km}^{-1} \cdot$ year $\left.^{-1}\right)$.

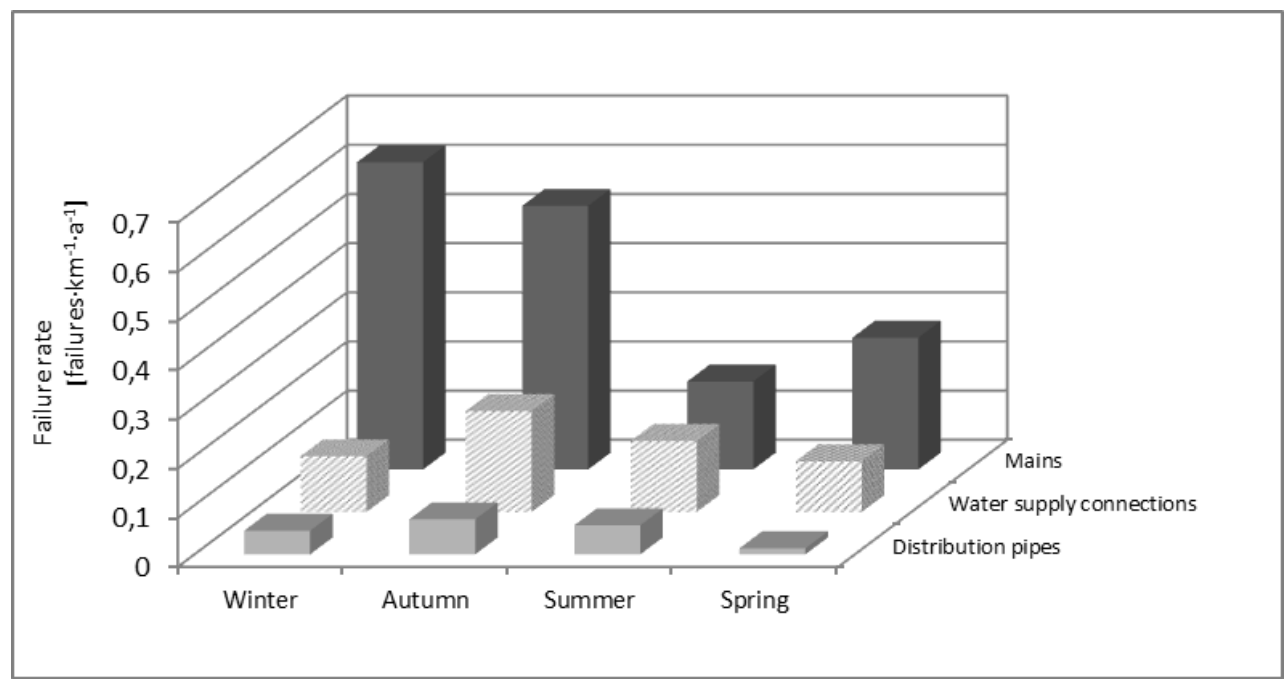

Fig. 5. The failure rate of water pipe network in division into seasons and water pipe function in the years 2002-2015

\section{Conclusions}

The presented analysis showed a downward trend in the number of failures in the analysed years. The characteristic seasonality of the number of failures with high values in the winter months, increased number of failures in summer and lower failure frequency in the spring season, was observed. Material composition of water supply system shows the advantage of plastics, systematic exchange of pipes made of cast iron for pipes made of PE is observed, last year almost $40 \%$ of the total length of the network was made of PE. The obtained values were referred to the average failure rate of water supply network determined for eight cities in Podkarpackie [8], which in 2015 for the mains was 0.92 failures $\mathrm{km}^{-1} \cdot \mathrm{year}^{-1}$, for the distributional pipes 0.20 failures $\mathrm{km}^{-1} \cdot$ year $^{-1}$ and for the water supply connections 0.35 failures $\cdot \mathrm{km}^{-1} \cdot$ year $^{-1}$. Except for the distributional pipes, the higher values than found in rest cities of the province were observed. 
Taking into account the type of used material, for PVC and PE the failure rate amounted to, respectively, 0.18 failures $\mathrm{km}^{-1} \cdot \mathrm{year}^{-1}$ and 0.09 failures $\cdot \mathrm{km}^{-1} \cdot \mathrm{year}^{-1}$ and for PVC it was higher compared to national conditions $\left(\lambda_{\mathrm{PVC}}=0.09\right.$ failures $\cdot \mathrm{km}^{-}$ ${ }^{1}$. year $^{-1}$ and $\lambda_{\mathrm{PE}}=0.08$ failures $\mathrm{km}^{-1} \cdot \mathrm{year}^{-1}$ ) [6]. For pipes made of cast iron the failure rate of 0.38 failures $\mathrm{km}^{-1} \cdot \mathrm{year}^{-1}$ was obtained, in comparison to $\lambda_{\text {greyiron }}=$ 0.47 failures $\mathrm{km}^{-1} \cdot \mathrm{year}^{-1}$ and for galvanized steel 1.17 failures $\mathrm{km}^{-1} \cdot \mathrm{year}^{-1}$. compared to national conditions 0.83 failures $\cdot \mathrm{km}^{-1} \cdot \mathrm{rok}^{-1}$. In the analysed water supply system the failure frequency of the distributional pipes and water supply connections is lower than the criteria value [10] and tends to decrease. However, in the case of mains the failure rate is about seven times higher. The results allow to assesss the state of water supply network as good, which undoubtedly was influenced by replacing old pipes, as well as the modernization and expansion of the water supply network.

\section{References}

[1] Dohnalik P., Jędrzejewski A.: Efektywna eksploatacja wodociągów. LEMtech Konsulting, Kraków 2004.

[2] Hastak M., Baim E.: Risk factors affecting management and maintenance cost of urban infrastructure, Journal of Infrastructure System, 2/2001, pp. 67-75.

[3] Herbert H.: Technical and economic criteria determining the rehabilitation and for renewal of drinking water pipelines. Proceedings of IWSA Regional Conference, Zurich 1994, s. 111-123.

[4] Hotloś H.: Ilościowa ocena wpływu wybranych czynników na parametry i koszty eksploatacyjne sieci wodociągowych. Prace Naukowe Instytutu Inżynierii Ochrony Środowiska Politechniki Wrocławskiej, Oficyna Wydawnicza Politechniki Wrocławskiej, Wrocław 2007.

[5] Kujawska K., Rak J.: Analiza i ocena strat wody wodociągu miasta Mielca. Czasopismo Inżynierii Lądowej, Środowiska i Architektury, Journal of Civil Engineering, Environment and Architecture, JCEEA, z. 63 (2/I/2016), s.445-454. DOI: $10.7862 / \mathrm{rb} .2016 .143$

[6] Kwietniewski M., Rak J.: Niezawodność infrastruktury wodociągowej i kanalizacyjnej w Polsce. Polska Akademia Nauk. Komitet Inżynierii Lądowej i Wodnej. Instytut Podstawowych Problemów Techniki. Warszawa 2010.

[7] Kwietniewski M., Roman M., Kłoss-Trębaczkiewicz H.: Niezawodność wodociągów i kanalizacji. Arkady, Warszawa 1993.

[8] Pietrucha-Urbanik K., Bernacka A.: Analysis of Water Infrastructure Development - a Case Study of the Exemplary Water Supply System. Czasopismo Inżynierii Lądowej, Środowiska i Architektury, Journal of Civil Engineering, Environment and Architecture, JCEEA, z. 63 (3/2016), s. 221-230. DOI: $10.7862 / \mathrm{rb} .2016 .124$

[9] Pietrucha-Urbanik K.: Failure analysis and assessment on the exemplary water supply network. Engineering Failure Analysis, 57/2015, pp. 137-142. DOI: 10.1016/j.engfailanal.2015.07.036 
Analysis and assessment of water distribution subsystem failure Analiza i ocena awaryjności podsystemu dystrybucji wody

[10] Rak J.: Podstawy bezpieczeństwa systemów zaopatrzenia w wodę. Komitet Inżynierii Środowiska PAN. t. 28, 2005.

[11] Rak, J., Pietrucha-Urbanik, K. New directions for the protection and evolution of water supply systems - smart water supply. Czasopismo Inżynierii Lądowej, Środowiska i Architektury - Journal of Civil Engineering, Environment And Architecture. JCEEA, z. 62 (3/I/2015), pp. 365-373. DOI: $10.7862 / \mathrm{rb} .2015 .121$

[12] Ustawa $\mathrm{z}$ dnia 7 czerwca 2001 r. o zbiorowym zaopatrzeniu w wodę i zbiorowym odprowadzaniu ścieków (Dz. U. Dz.U. z $2001 \mathrm{nr} 72$ poz. 747 z późniejszymi zmianami). Act of 7 June 2001 about the collective water supply and discharge of wastewater (Journal of Laws of 2001, No. 72, item. 747 , as amended).

[13] Tchórzewska-Cieślak B., Szpak D.: Propozycja metody analizy i oceny bezpieczeństwa dostawy wody. Ochrona Srodowiska 2015, Vol. 37, No. 3, pp. 43-47.

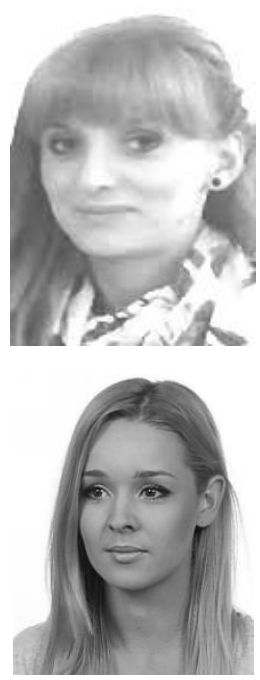

Katarzyna Pietrucha-Urbanik is currently working as an adjunct at Rzeszow University of Technology, Department of Water Supply and Sewage systems. Specialization - water supply systems, reliability and safety analyses of municipal systems (Share 50\%).

Katarzyna Pociask in 2016 finished study on Faculty of Civil, Environmental Engineering and Architecture at Rzeszow University of Technology. Specialization: water supply system, failure of water network (Share 50\%). 


\section{ANALIZA I OCENA AWARYJNOŚCI PODSYSTEMU DYSTRYBUCJI WODY}

\section{Wstęp}

Awarie występujące na sieciach wodociągowych dotyczą każdego jego eksploatowanego elementu, aczkolwiek intensywność uszkodzeń każdej części jest różna i zależy między innymi od rodzaju zastosowanego materiału, bądź czasu eksploatacji sieci wodociągowej $[2,8]$. Efektem awarii może być spadek ciśnienia w sieci i straty wody $[1,9,10]$. Przedsiębiorstwa wodociągowe dążą do minimalizacji strat wody, jak również liczby występujących awarii. W tym celu prowadzona jest analiza funkcjonowania systemu wodociągowego, której celem jest zobrazowanie w jakim stanie znajduje się dana sieć wodociągowa. W wielu ośrodkach naukowych prowadzone są badania dotyczące prawidłowego funkcjonowania sieci wodociągowej [3-5, 13]. Analizy te dotyczą awaryjności sieci wodociągowej między innymi pod kątem przyczyn występowania awarii, rodzaju uszkodzeń oraz ich liczby. Jednym ze wskaźników przedstawiający stan danego odcinka sieci wodociągowej jest intensywność uszkodzeń, która może stanowić podstawę do planowania strategii odnowy sieci wodociągowej, mającej na celu zmniejszenie liczby uszkodzeń sieci, a tym samym zapewnienie ciągłych dostaw wody do odbiorców [13]. Z tego powodu w pracy przedstawiono analizę i ocenę awaryjności sieci wodociągowej w ostatnich dziesięciu latach dla wybranego miasta w województwie podkarpackim, liczącego 39375 mieszkańców o powierzchni $38,08 \mathrm{~km}^{2}$.

\section{Charakterystyka analizowanej sieci wodociągowej}

Analizowana sieć wodociągowa pracuje w układzie pierścieniowo promienistym. W 2015 roku długość tej sieci wynosiła $342,71 \mathrm{~km}$. Prawie 60\% całej długości sieci stanowią odcinki nie mające więcej niż 10 lat, odcinki do 25 lat stanowią $30 \%$, pozostały procent stanowią odcinki sięgające blisko 50 lat. W 2015 r. 39\% stanowiły odcinki z PE, $31 \%$ z żeliwa szarego, $16 \%$ z PVC oraz $14 \%$ ze stali. Można zauważyć stopniowe zmniejszanie sieci wodociągowej wykonanej z żeliwa szarego i stalowej, a bardzo duży wzrost przewodów wykonanych z PE (Rys.1).

Największa zmiana w strukturze materiałowej wystąpiła w 2013 roku, odcinki żeliwne i stalowe zostały wymienione i zastąpione przewodami wykonanymi z PE. Na przestrzeni analizowanych 14 lat sieć wodociągowa zwiększyła się z 174,2 km do $342,71 \mathrm{~km}$, co daje prawie $97 \%$ wzrost długości sieci. Co roku długość sieci rozrastała się o kilka kilometrów, bardzo duży przyrost $(43,9 \mathrm{~km})$ miał miejsce w 2013 roku, co było efektem rozbudowy stacji uzdatniania wody w Trepczy. Z kolei w 2015 roku długość sieci wydłużyła się o $66 \mathrm{~km}$, czyli o 24\%. Długość sieci magistralnej przez te wszystkie lata pozostała niezmienna, podobnie jak przyłącza wodociągowe w latach 2002-2012. 
Analysis and assessment of water distribution subsystem failure Analiza i ocena awaryjności podsystemu dystrybucji wody

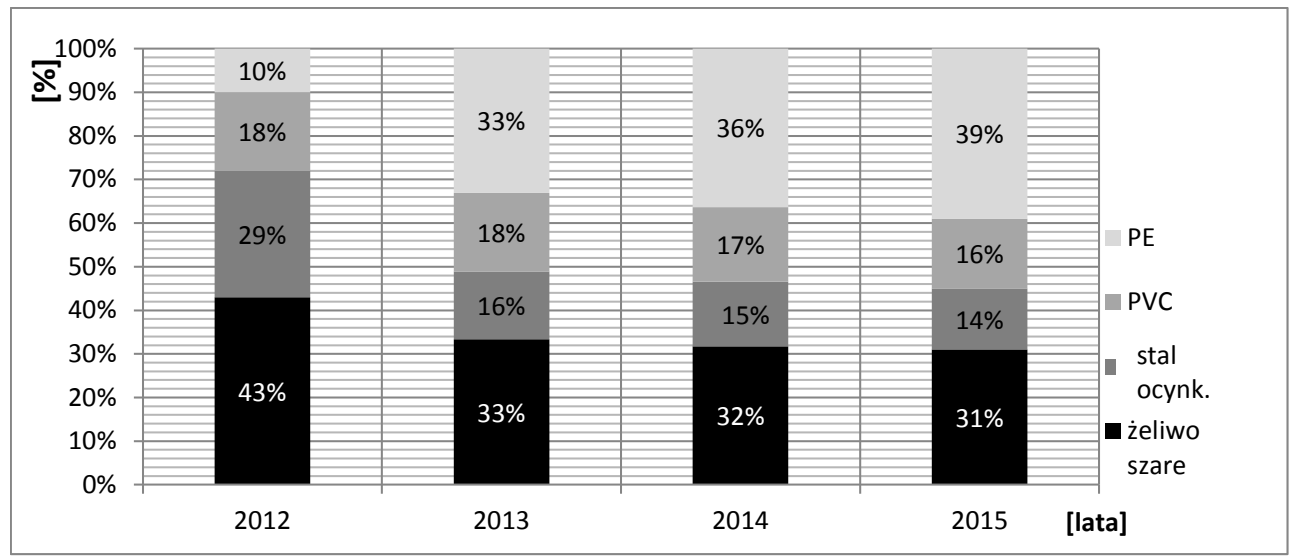

Rys. 3. Procentowa struktura materiałowa w latach 2012-2015.

$\mathrm{Na}$ przestrzeni analizowanych lat produkcja wody kształtowała się na równomiernym poziomie. Od 2011 roku wielkość produkcji cały czas malała przyjmując w 2014 roku najniższą na przestrzeni 14 lat wartość (spadek wielkości produkcji o 13\%). Ilość wody wtłoczonej do sieci jest mniejsza niż wody pobranej o około 6-7\%. Procentowe zużycie wody przed wtłoczeniem do sieci w latach 2002-2012 waha się w granicach 4,5-6\%, a w latach 2013-2015 wartość ta wzrosła niemal dwukrotnie.

Najwięcej wody zostało sprzedanej do gospodarstw domowych (76\%), do innych użytkowników takich jak urzędy, szpitale, szkoły $17 \%$, a pozostałe $6 \%$ to woda sprzedana na cele przemysłowe. Sprzedaż wody w ciągu 14 lata zmalał o ponad $22 \%$. Biorąc pod uwagę fakt, że w tych latach długość sieci wodociągowej znacznie wzrosła można przypuszczać, że powodem takiego spadku sprzedaży wody może być m.in. zamykanie zakładów przemysłowych oraz budowa własnych ujęć wody. Porównując sprzedaż wody na cale przemysłowe w 2002 roku do sprzedaży w roku 2015, można zauważyć znaczny spadek, który wyniósł $72 \%$. Również u innych odbiorców sprzedaż zmalała o $26 \%$, najmniej bo o $15 \%$ zmniejszyła się sprzedaż wody do gospodarstw domowych.

\section{Analiza awaryjności sieci wodociągowej}

\section{Intensywność uszkodzeń sieci w zależności od funkcji przewodu}

Intensywność uszkodzeń sieci wyznaczono jako liczbę awarii przypadającą na długość przewodu [7]. Wartości graniczne intensywności uszkodzeń w zależności od rodzaju przewodu są następujące: dla przewodów magistralnych $\lambda \leq 0,3$ uszk. $\cdot \mathrm{km}^{-1} \cdot \mathrm{rok}^{-1}$, dla przewodów rozdzielczych $\lambda \leq 0,5 \mathrm{uszk} \cdot \mathrm{km}^{-1} \cdot \mathrm{rok}^{-1}$ oraz dla przyłączy wodociągowych $\lambda \leq 1,0$ uszk. $\mathrm{km}^{-1} \cdot \mathrm{rok}^{-1}$. Analizując dane przedstawione na rysunku 2 można zauważyć, że największą awaryjnością charakteryzują się przewody magistralne. 
Średnia intensywność uszkodzeń na tych przewodach w latach od 2006 do 2015 wynosiła 1,78 uszk. $\cdot \mathrm{km}^{-1} \cdot \mathrm{rok}^{-1}$. Liczba występujących awarii na tych odcinkach nie jest duża bo waha się w zakresie od 14 do 26 , jednak w stosunku do długości sieci $11,2 \mathrm{~km}$ daje to najwyższy wskaźnik. $Z$ kolei średnia intensywność przyłączy wodociągowych wynosi 0,84 uszk. $\cdot \mathrm{km}^{-1} \cdot \mathrm{rok}^{-1}$, natomiast na przewodach rozdzielczych średnia intensywność uszkodzeń wyniosła zaledwie 0,39 uszk. $\cdot \mathrm{km}^{-1} \cdot$ rok $^{-1}$.

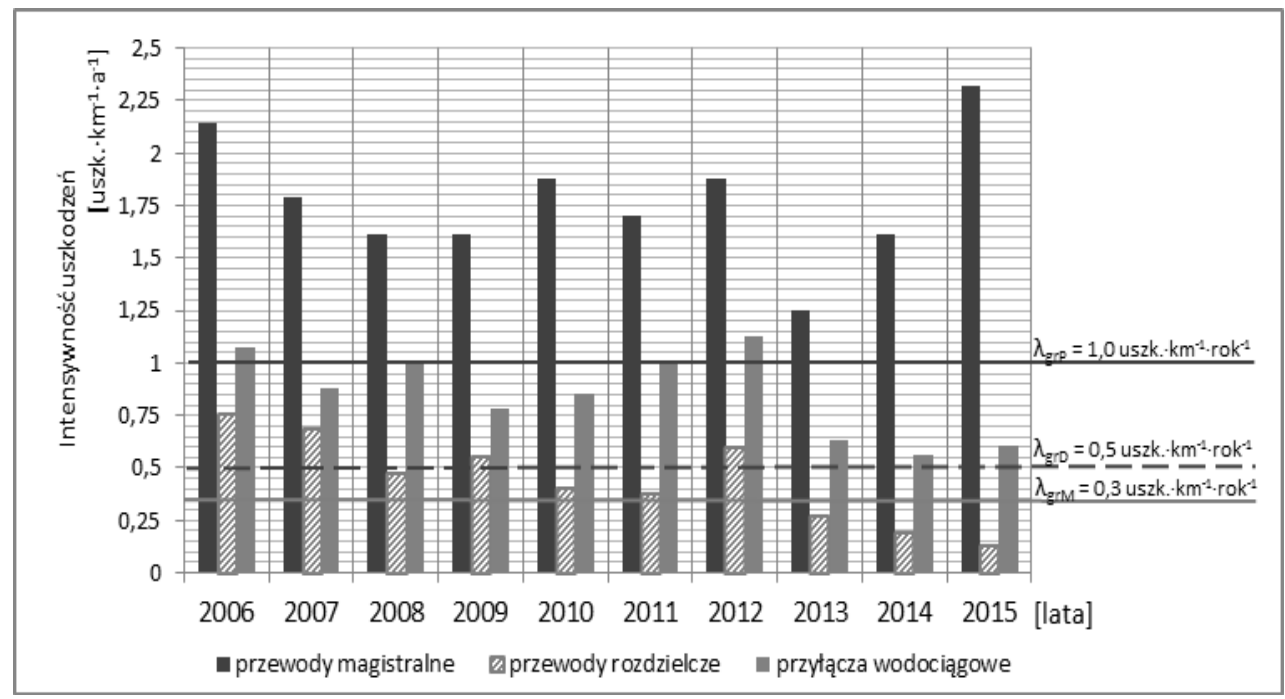

Rys. 4. Intensywność uszkodzeń poszczególnych przewodów sieci wodociagowej w latach 2006-2015

Według kryteriów przyjętych w Polsce wynika, że przewody magistralne prawie sześciokrotnie przewyższają zalecaną wartość [10]. Od 2013 roku wskaźnik intensywności uszkodzeń przewodów rozdzielczych wykazywał wyraźna tendencję malejącą, na skutek wymiany sporej części sieci oraz zastosowania materiałów z tworzyw sztucznych, jak również znacznego przyrostu sieci o $37 \% \mathrm{w}$ okresie trzech ostatnich lat. W ostatnich latach analizy intensywność uszkodzeń przyłączy wodociągowych była mniejsza od granicznej wartości $\left(\lambda_{\mathrm{grP}} \leq 1,0 \mathrm{uszk} \cdot \mathrm{km}^{-1} \cdot \mathrm{rok}^{-1}\right)$, tylko w latach 2006, 2008 i 2012 intensywność przekraczała kryterialną wartość.

\section{Intensywność uszkodzeń sieci w zależności od materiału przewodu}

$\mathrm{Na}$ rysunku 3 przedstawiono intensywność uszkodzeń $\mathrm{z}$ podziałem na rodzaj zastosowanego materiału w latach 2002-2015.

Najbardziej awaryjne są przewody wykonane ze stali ocynkowanej. Wskaźnik intensywności uszkodzeń na tych przewodach w poszczególnych latach z wyjątkiem 2012 roku jest najwyższy. Na przestrzeni lat najmniej awaryjne przewody były wykonane z PCV, a od 2013 roku sieć wykonana z PE. 
Analysis and assessment of water distribution subsystem failure Analiza i ocena awaryjności podsystemu dystrybucji wody

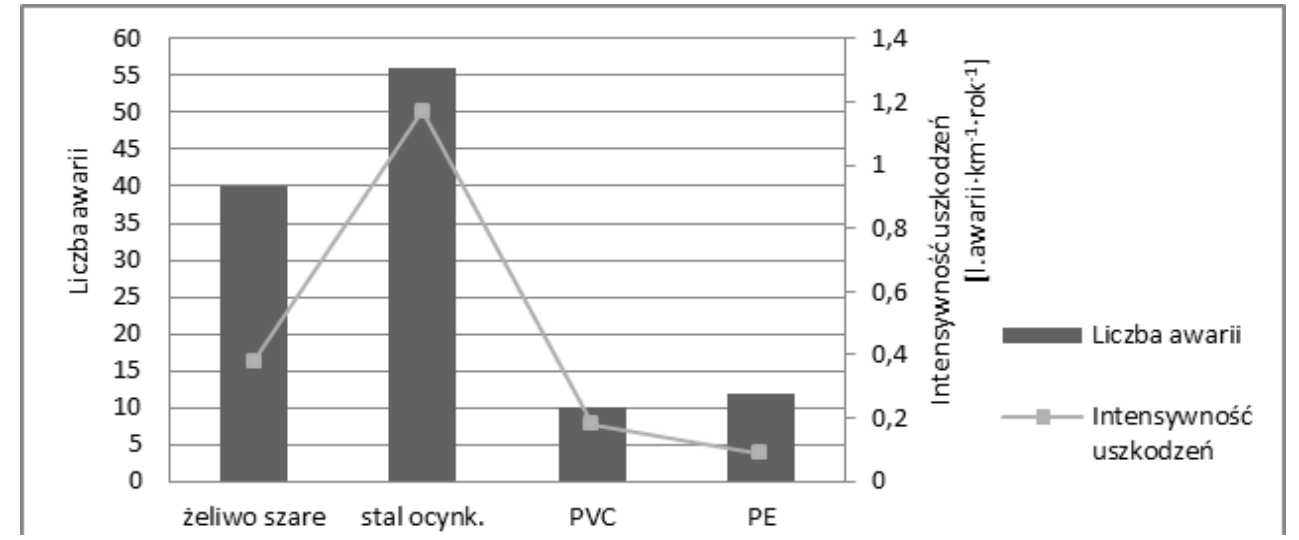

Rys. 5. Jednostkowa intensywność uszkodzeń z podziatem na rodzaj zastosowanego materiatu w2015 roku

\section{Sezonowość intensywności uszkodzeń}

Na rysunku 4 przedstawiono wartości intensywności uszkodzeń z podziałem na pory roku w latach 2006-2015. Natomiast na rysunku 4 intensywność uszkodzeń ze względu na funkcję przewodu oraz sezonowość uszkodzeń.

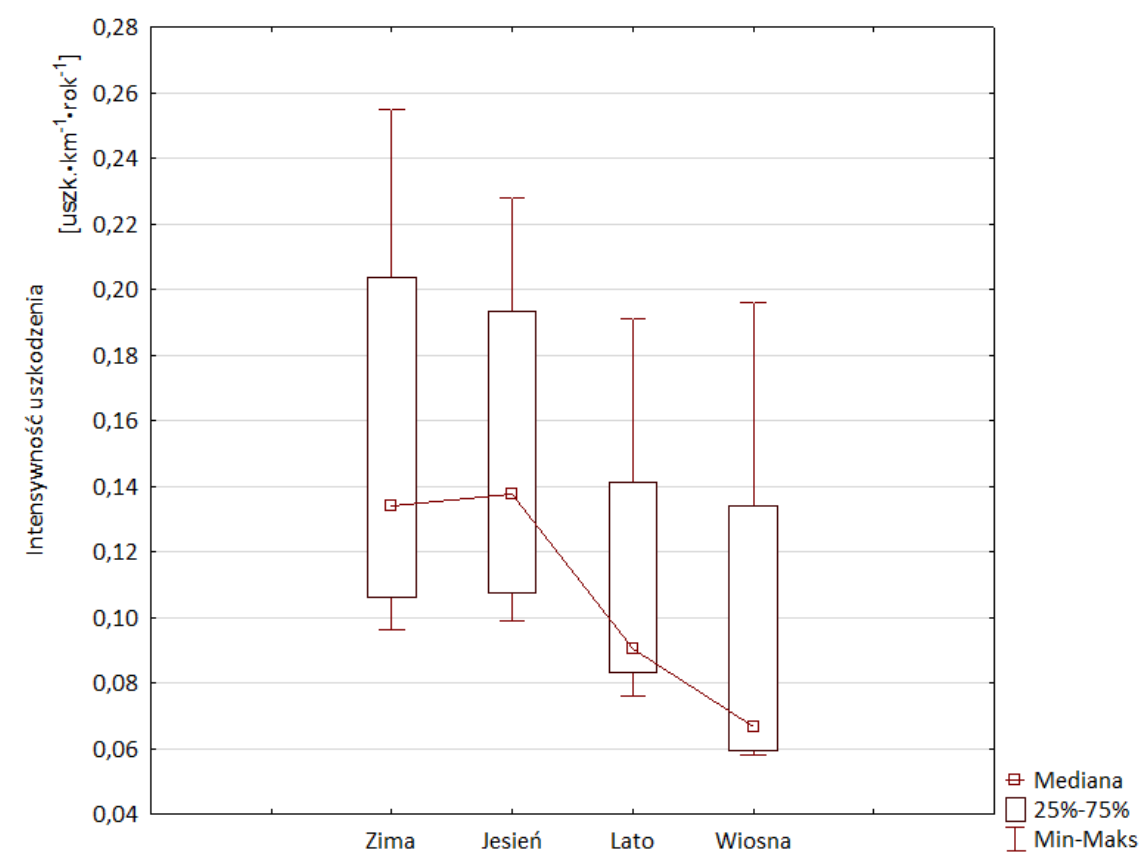

Rys. 6. Intensywności uszkodzeń przewodów wodociagowych z podziatem na pory roku w latach 2006-2015. 
Średnia wartość wskaźnika intensywności uszkodzeń jest największa w sezonie zimowym i wynosi $0,1547 \mathrm{uszk} \cdot \mathrm{km}^{-1} \cdot \mathrm{rok}^{-1}$. Najniższa wartość tego wskaźnika występuje na wiosnę, wtedy jego średnia wartość wynosi $0,096 \mathrm{uszk} \cdot \mathrm{km}^{-1} \cdot \mathrm{rok}^{-1}$. Z kolei w 2015 roku największy wskaźnik intensywności uszkodzeń występuje na przewodach magistralnych, w czerwcu wyniósł 0,446 uszk. $\cdot \mathrm{km}^{-1} \cdot \mathrm{rok}^{-1}$, a w kwietniu, listopadzie i grudniu $0,268 \mathrm{uszk} \cdot \mathrm{km}^{-1} \cdot \mathrm{rok}^{-1}$. W czerwcu 2015 roku przewody rozdzielcze charakteryzowały się wartością intensywności wynoszącą $0,022 \mathrm{uszk} \cdot \mathrm{km}^{-1} \cdot \mathrm{rok}^{-1}$, natomiast intensywność uszkodzeń przyłączy wodociągowych w tym czasie osiągnęly wartość wynoszącą 0,07 uszk. $\mathrm{km}^{-1} \cdot \mathrm{rok}^{-1}$, przy maksymalnej wartości występującej w grudniu $\left(0,12 \mathrm{uszk} \cdot \mathrm{km}^{-1} \cdot \mathrm{rok}^{-1}\right)$.

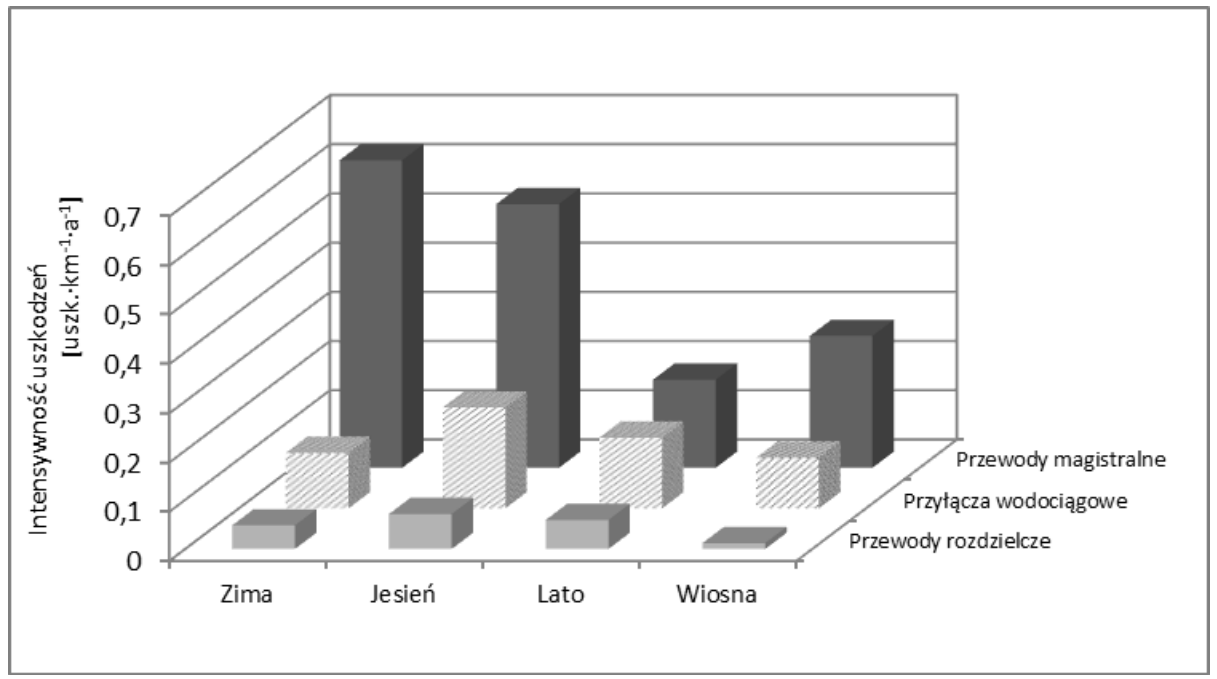

Rys. 7. Intensywności uszkodzeń przewodów wodociagowych z podziałem na pory roku oraz funkcje przewodu wodociagowego w latach 2006-2015.

\section{Wnioski}

Przedstawiona analiza wykazała tendencję malejącą liczby awarii w omawianych latach. Zaobserwowano charakterystyczną sezonowość liczby awarii z wysokimi wartościami $\mathrm{w}$ miesiącach zimowych, podwyższonymi w letnich oraz mniejszą awaryjność w sezonie wiosennym.

Struktura materiałowa sieci wodociągowej wykazuje przewagę materiałów z tworzyw sztucznych, notuje się systematyczną wymianę przewodów wykonanych z żeliwa szarego na przewody wykonane z PE, które w ostatnim roku stanowiły blisko $40 \%$ długości całej sieci. Otrzymane wartości odniesiono do średniej uszkadzalności sieci wodociągowych wyznaczonej dla ośmiu miast w województwie podkarpackim [8], która w 2015 roku dla przewodów magistralnych wynosiła $0,92 \mathrm{uszk} \cdot \mathrm{km}^{-1} \cdot \mathrm{rok}^{-1}$, a dla przewodów rozdzielczych 0,20 uszk $\cdot \mathrm{km}^{-1} \cdot \mathrm{rok}^{-1}$ oraz przyłączy wodociągowych $0,35 \mathrm{uszk} \cdot \mathrm{km}^{-1} \cdot \mathrm{rok}^{-1}$. 
Analysis and assessment of water distribution subsystem failure Analiza i ocena awaryjności podsystemu dystrybucji wody

Za wyjątkiem przewodów rozdzielczych zaobserwowano wartości wyższe od występujących w pozostałych miastach województwa. Biorąc pod uwagę rodzaj zastosowanego materiału dla PVC i PE intensywność uszkodzeń wynosiła odpowiednio 0,18 uszk. $\cdot \mathrm{km}^{-1} \cdot \mathrm{rok}^{-1}$ oraz $0,09 \mathrm{uszk} \cdot \mathrm{km}^{-1} \cdot \mathrm{rok}^{-1} \mathrm{i}$ w przypadku PVC była większa w porównaniu do warunków krajowych $\left(\lambda_{\mathrm{PVC}}=0,09\right.$ uszk. $\cdot \mathrm{km}^{-1} \cdot \mathrm{rok}^{-1}$ i $\lambda_{\text {PE }}=0,08$ uszk. $\cdot \mathrm{km}^{-1} \cdot \operatorname{rok}^{-1}$ ) [10]. Dla przewodów z żeliwa szarego otrzymano intensywność wynoszącą $0,38 \mathrm{uszk} \cdot \mathrm{km}^{-1} \cdot \mathrm{rok}^{-1}$ wobec $\lambda_{\text {żelszar }}=0,47 \mathrm{uszk} \cdot \mathrm{km}^{-1} \cdot \mathrm{rok}^{-1}$ oraz dla stali ocynkowanej $1,17 \mathrm{uszk} \cdot \mathrm{km}^{-1} \cdot \operatorname{rok}^{-1} \mathrm{w}$ porównaniu do warunków krajowych 0,83 uszk $\cdot \mathrm{km}^{-1} \cdot \mathrm{rok}^{-1}$. W rozpatrywanej sieci wodociągowej uszkadzalność przewodów rozdzielczych oraz przyłączy wodociągowych jest niższa od wartości kryterialnej [10] oraz wykazuje tendencje malejącą. Natomiast w przypadku przewodów magistralnych około siedmiokrotnie wyższa. Otrzymane wyniki pozwalają na dobrą ocenę stanu sieci wodociągowej, na co niewątpliwie wpływa wymiana przestarzałych przewodów, modernizacja i rozbudowa sieci wodociągowej.

\section{Literatura}

[1] Dohnalik P., Jędrzejewski A.: Efektywna eksploatacja wodociągów. LEMtech Konsulting, Kraków 2004.

[2] Hastak M., Baim E.: Risk factors affecting management and maintenance cost of urban infrastructure, Journal of Infrastructure System, 2/2001, pp. 67-75.

[3] Herbert H.: Technical and economic criteria determining the rehabilitation and for renewal of drinking water pipelines. Proceedings of IWSA Regional Conference, Zurich 1994, s. 111-123.

[4] Hotloś H.: Ilościowa ocena wpływu wybranych czynników na parametry i koszty eksploatacyjne sieci wodociągowych. Prace Naukowe Instytutu Inżynierii Ochrony Środowiska Politechniki Wrocławskiej, Oficyna Wydawnicza Politechniki Wrocławskiej, Wrocław 2007.

[5] Kujawska K., Rak J.: Analiza i ocena strat wody wodociągu miasta Mielca. Czasopismo Inżynierii Lądowej, Środowiska i Architektury, Journal of Civil Engineering, Environment and Architecture, JCEEA, z. 63, nr 2/I/2016, s.445-454. DOI: 10.7862/rb.2016.143

[6] Kwietniewski M., Rak J.: Niezawodność infrastruktury wodociągowej i kanalizacyjnej w Polsce. Polska Akademia Nauk. Komitet Inżynierii Lądowej i Wodnej. Instytut Podstawowych Problemów Techniki. Warszawa 2010.

[7] Kwietniewski M., Roman M., Kłoss-Trębaczkiewicz H.: Niezawodność wodociągów i kanalizacji. Arkady, Warszawa 1993.

[8] Pietrucha-Urbanik K., Bernacka A.: Analysis of Water Infrastructure Development - a Case Study of the Exemplary Water Supply System. Czasopismo Inżynierii Lądowej, Środowiska i Architektury, Journal of Civil Engineering, Environment and Architecture, JCEEA, z. 63, nr 2/I/2016, s. 221-230. DOI: $10.7862 / \mathrm{rb} .2016 .124$ 
[9] Pietrucha-Urbanik K.: Failure analysis and assessment on the exemplary water supply network. Engineering Failure Analysis, 57/2015, pp. 137-142. DOI: 10.1016/j.engfailanal.2015.07.036

[10] Rak J.: Podstawy bezpieczeństwa systemów zaopatrzenia w wodę. Komitet Inżynierii Środowiska PAN. t. 28, 2005.

[11] Rak, J., Pietrucha-Urbanik, K. New directions for the protection and evolution of water supply systems - smart water supply. Czasopismo Inżynierii Lądowej, Srodowiska i Architektury - Journal of Civil Engineering, Environment And Architecture. JCEEA, z. 62, nr 3/I/2015, pp. 365-373. DOI: $10.7862 / \mathrm{rb} .2015 .121$

[12] Ustawa $\mathrm{z}$ dnia 7 czerwca 2001 r. o zbiorowym zaopatrzeniu w wodę i zbiorowym odprowadzaniu ścieków (Dz. U. Dz.U. z $2001 \mathrm{nr} 72$ poz. 747 z późniejszymi zmianami).

[13] Tchórzewska-Cieślak B., Szpak D.: Propozycja metody analizy i oceny bezpieczeństwa dostawy wody. Ochrona Środowiska 2015, Vol. 37, No. 3, pp. 43-47.

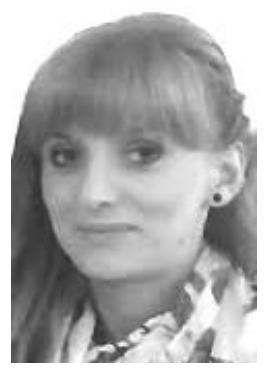

Dr inz. Katarzyna Pietrucha-Urbanik pracuje na stanowisku adiunkta w Zaktadzie Zaopatrzenia w Wodę i Odprowadzania Ścieków Politechniki Rzeszowskiej. Specjalizacja: systemy wodociagowe, niezawodność i bezpieczeństwo systemów komunalnych (Udziat 50\%).

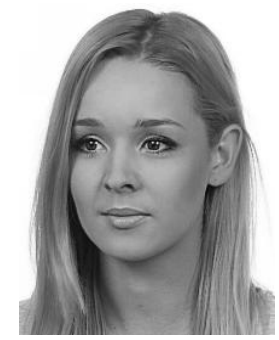

Mgr inż. Katarzyna Pociask w 2016 roku ukończyła studia na Wydziale Budownictwa, Inżynierii Środowiska i Architektury Politechniki Rzeszowskiej. Zainteresowania naukowe: systemy wodociagowe, awaryjność sieci wodociagowych (Udział 50\%). 
Analysis and assessment of water distribution subsystem failure Analiza i ocena awaryjności podsystemu dystrybucji wody 